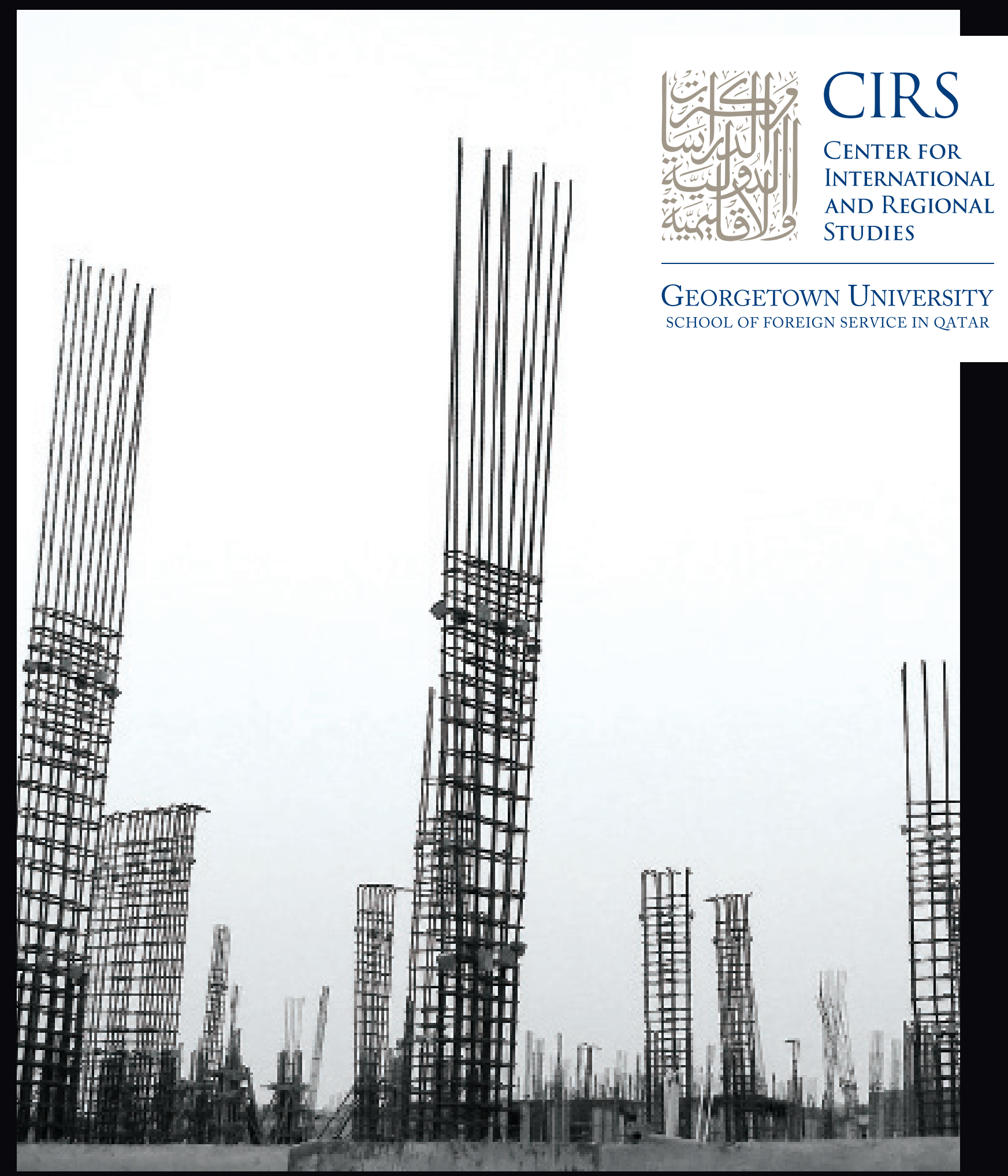

\title{
The Political Economy of the Gulf
}

\section{Summary Report}




\section{About the Georgetown University School of Foreign Service in Qatar}

The Georgetown University School of Foreign Service in Qatar, opened in August 2005, is a branch campus of Georgetown University, the oldest Catholic and Jesuit university in America, founded in 1789. The program builds on Georgetown University's long tradition of educating future leaders for careers in the international arena through a liberal arts undergraduate program focused on international affairs. For more information about the School of Foreign Service in Qatar, please visit http://qatar.sfs.georgetown.edu.

\section{About the Center for International and Regional Studies}

Established in 2005, the Center for International and Regional Studies at the Georgetown University School of Foreign Service in Qatar is a premier research institute devoted to the academic study of regional and international issues through dialogue and exchange of ideas, research and scholarship, and engagement with national and international scholars, opinion makers, practitioners, and activists.

Guided by the principles of academic excellence, forward vision, and community engagement, the Center's mission revolves around five principal goals:

- To provide a forum for scholarship and research on international and regional affairs

- To encourage in-depth examination and exchange of ideas

- To foster thoughtful dialogue among students, scholars and practitioners of international affairs

- To facilitate the free flow of ideas and knowledge through publishing the products

of its research, sponsoring conferences and seminars, and holding workshops

designed to explore the complexities of the twenty-first century

- To engage in outreach activities with a wide range of local, regional, and international partners

\section{About the Qatar Foundation for Education, Science and Community Development}

Founded in 1995, Qatar Foundation is a private, non-profit, chartered organization committed to the principle that a nation's greatest resource is its people. Qatar Foundation is headquartered in a unique Education City, which hosts numerous progressive learning institutions and centers of research, including branch campuses of five of the world's leading universities. For more information, please visit www.qf.org.qa

This publication is made possible by the generous support of Qatar Foundation for Education, Science and Community Development.

(C) Cover photograph by Patty Paine Gibbons (Doha, 2006). 


\section{The Political Economy of the Gulf Working Group Summary Report}

C) 2011 Center for International and Regional Studies Georgetown University School of Foreign Service in Qatar 


\section{The Political Economy of the Gulf \\ Working Group Summary Report}

The CIRS research project on "The Political Economy of the Gulf" was launched in 2009. As with other CIRS research initiatives, after a thorough review of existing literature on the topic, certain gaps were identified meriting further original research and scholarship. Select scholars were invited to participate in a working group for focused discussions on a range of sub-topics. During these meetings the participants contributed their expertise, and began working on papers in their specialty areas. The ultimate product of this research project will be an edited book on "The Political Economy of the Gulf." The working group meetings held in Doha, Qatar, meant that authors were able to work closely together in order for the individual chapters to cross-reference each other for better coherence and intellectual synergy of the volume. Each study is an in-depth work of scholarship that is original, analytical, and makes a significant contribution to the field.

"The Political Economy of the Gulf" research initiative highlights the rapid changes that have occurred in the states of the Gulf Cooperation Council (GCC) in recent years. While some of these countries have capitalized upon the fast-paced nature of globalized fiscal transactions and have become important markets for foreign investment, others have fallen victim to such speculations. The once awe-inspiring and sought-after "Dubai Model" of economic diversification is being re-evaluated as the GCC states continue to seek the best means of organizing their economies and competing within the global order. The GCC states continue to find their footing on the international stage as they attempt to establish knowledge-based economies within the overarching framework of rentierism and outgrow their dependence upon hydrocharbon industries. The GCC states' various diversification plans have signaled official acknowledgment of the necessity of changing the ways in which their economies operate and of investing in a future based on the potentials of human capital, rather than relying solely on oil and rents.

These economic and political reform efforts that are currently underway in most of the GCC states have attempted to enhance political stability both regionally and internationally in order to increase the region's international bargaining power.

Explaining the different ways in which globalizing forces have shaped new dimensions to the political economy of the Gulf states, this research initiative proposes to evaluate the changes that have occurred, especially in light of the ongoing global economic crisis. Mutually beneficial rentier arrangements have guided the means in which the GCC countries have formed their oil-based economies and labor relations in the past, but will this necessarily be the case in the years to come? In order to fully realize the political economic situation of the region, the chapters in the upcoming book address key issues including discussion on the future demographic aspects of the GCC; the feasibility of establishing a GCC monetary union; the effects of rentierism on state autonomy; and analysis of sovereign wealth funds and Islamic banking models, among other central issues. 
The Political Economy of the Gulf

Working Group Participants and Contributors

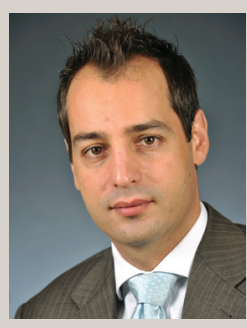

Alexis Antoniades

Georgetown University

School of Foreign Service

in Qatar

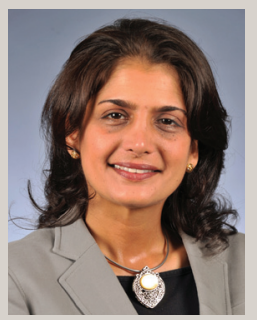

Zahra Babar

Georgetown University

School of Foreign Service in Qatar

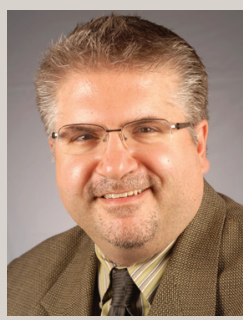

John T. Crist

Georgetown University

School of Foreign Service

in Qatar

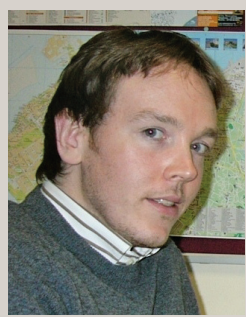

Christopher Davidson

Durham University

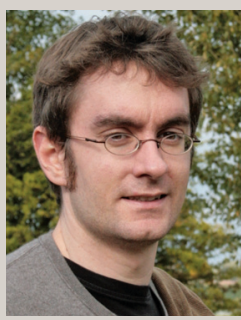

Steffen Hertog

London School of Economics and

Political Science

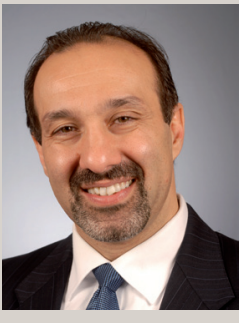

Mehran Kamrava

Georgetown University

School of Foreign Service in Qatar

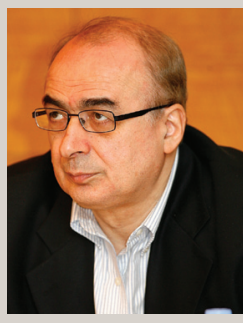

Massoud Karshenas

School of Oriental and African

Studies, University of London

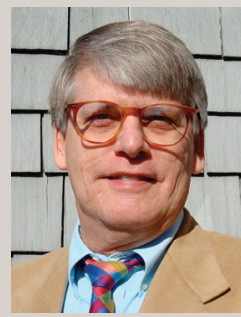

Fred H. Lawson

Mills College 


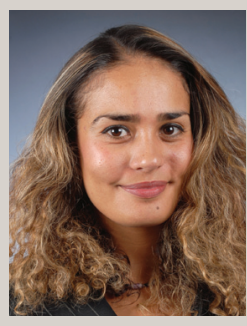

Suzi Mirgani

Georgetown University

School of Foreign Service

in Qatar

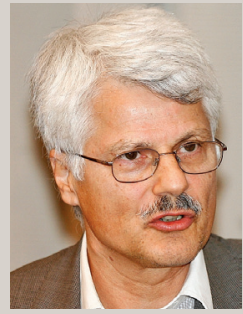

Djavad Salehi-Isfahani

Virginia Polytechnic Institute

and State University

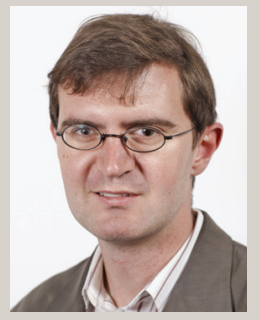

Kristian Coates Ulrichsen

London School of Economics and Political Science

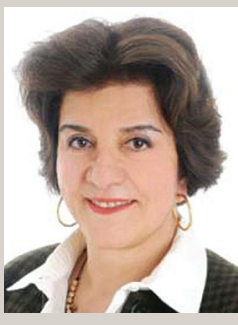

Ziba Moshaver

School of Oriental and African

Studies, University of London

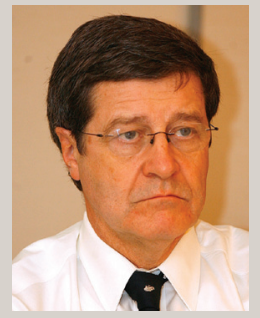

Jean-François Seznec

Georgetown University

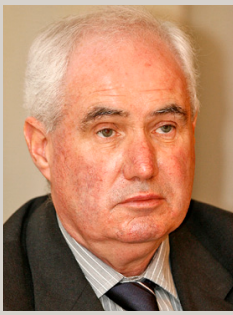

Rodney Wilson

Durham University 


\section{Table of Contents}

Paper Synopses

1. Introduction

Mehran Kamrava, Georgetown University School of Foreign Service in Qatar

Part I. Trends in the Political Economy of the Gulf

2. The Gulf in the Contemporary International Economy

Fred H. Lawson, Mills College

3. The Political Economy of Rentierism in the Gulf

Mehran Kamrava, Georgetown University School of Foreign Service in Qatar

4. The Sovereign Wealth Funds of the Gulf

Jean-François Seznec, Georgetown University

5. Knowledge Economies in the GCC States

Kristian Coates Ulrichsen, London School of Economics and Political Science

Part II. People, Money, and Banking in the Gulf

6. Étatisme Versus Market Driven Islamic Banking: The Experiences of Iran and the Arabian

Peninsula Compared

Rodney Wilson, Durham University

7. Population and Human Capital in the Persian Gulf

Djavad Salehi-Isfahani, Virginia Polytechnic Institute and State University

8. The Gulf Monetary Union

Alexis Antoniades, Georgetown University School of Foreign Service in Qatar

Part III. Case Studies

9. The Dubai Model: Diversification and Slowdown

Christopher Davidson, Durham University

10. Good, Bad, or Both? The Impact of Oil on the Saudi Political Economy

Steffen Hertog, London School of Economics and Political Science

11. The Political Economy of Rentierism in Iran

Massoud Karshenas and Ziba Moshaver, School of Oriental and African Studies, University of London 


\section{Introduction \\ Mehran Kamrava}

2011 turned out to be a historic year for the Middle East, and full of consequences of which are likely to take years and perhaps even decades to manifest themselves. For the foreseeable future, it is unclear whether the "Arab Spring" will usher in a wave of democratization and fundamentally change the nature of state-society interactions in the Middle East, as the Velvet Revolutions of East and Central Europe did in 1989, or eventually reinstate old patterns of nondemocratic rule under new guises. What is clear is that the mass-based rebellions that engulfed the Middle East from Morocco and Algeria in the west to Bahrain and Oman in the east all had their roots in fundamental contradictions in the politics and economics of the region. This book explores these contradictions in relation to a subsystem of the Middle East, namely the Gulf region.

At the broadest level, the political economy of the Gulf is characterized by three general sets of developments. First, by and large, Gulf states are engaged in rapid economic growth and efforts at fostering massive infrastructural development. In 2011, the countries of the Gulf Cooperation Council (GCC) were projected to have an economic growth rate of 7.8 percent, with their external current accounts surplus increasing from $\$ 136$ billion to $\$ 304$ billion on the back of rising oil prices. As with the preceding two decades, each of the governments used the windfall revenues to invest massively in infrastructural projects.

Second, for all countries of the region-though for some more successfully than for others, and with the exception of Iran - their herculean developmental efforts have been made possible through comparatively high levels of globalization and integration into the global economy, especially when compared with other parts of the Middle East. Significantly, state leaders across the GCC have framed globalization in terms consistent with evolving notions of nationalism. More specifically, they have presented global economic engagement as an integral aspect of the national project. What is key, they have maintained, is not necessarily ownership of the process of production and marketing of natural resources-i.e. hydrocarbons-but ownership over the outcome after those natural resources are marketed and sold. This framing of nationalism stands in sharp contrast to nationalist conceptions of yesteryears, say of Nasser, or of revolutionaries like Qaddafi and Khomeini, who saw the opening of the economy to outsiders as inviting exploitation by neocolonial powers. The outcome has been comparatively higher levels of global economic engagement among all GCC states. Global investors are attracted to the Gulf, one of the world's most profitable "energy zones," because of the region's business-friendly domestic and policy environments. For their part, the GCC states seek out new, lucrative markets in the West for investing their own sizeable sovereign wealth funds.

A third trend characterizing the political economy of most Gulf states has been efforts at laying the foundations for sustainable development once the oil era is over and hydrocarbon exports can no longer finance development at breakneck speed. To do so, most states in the region, especially the more wealthy ones, have sought to foster knowledge-based economies.

But, fostering knowledge-based economies requires more than building impressive edifices and creating educational hubs and enclaves. It also requires structural adjustments in related sectors of the economy, as well as concomitant shifts in cultural values and norms. Accurate empirical data on the phenomenon are also hard to come by. 
The three broad developmental efforts characterizing the political economy of the Gulf-rapid economic growth and infrastructural development, integration into the global economy, and the ushering in of knowledgebased economies- have in turn had to contend with three structural features that are endemic to all of the region's political economies. These include rentierism and its attendant consequences, demographic pressures, and other structural deficiencies that exert negative pressures and push back against developmental objectives. Since the start of the oil era in the Gulf, the region has witnessed the evolution of rentierism with paradoxical consequences: while rentierism has enabled the state to funnel oil and gas revenues into society and secure a measure of political acquiescence, it has also made the state dependent on maintaining its patronage position for fear of adverse consequences. Insofar as demographic pressures are concerned, the regional states are either far too populous given the state's resources and infrastructural capacities or are, alternatively, heavily reliant on imported labor to carry out their developmental agendas.

Finally, oil wealth by the state and conspicuous consumption on the part of the populace can mask structural weaknesses arising from dependence on hydrocarbon exports. The volatile growth of Gulf economies from the 1980s to the 2000s, emblematic of those of the rest of the Middle East, demonstrate their captive vulnerability to exogenous trends and directly reflect the turbulent cycle of the international oil market.

Most of the regional states have become major players in the global economy, for many the massive infusion of petrodollars into the economy has only partially masked — at times actually without much success— the pervasive structural weaknesses that continue to characterize their economies.

Mehran Kamrava is Director of the Center for International and Regional Studies at the Georgetown University School of Foreign Service in Qatar. He is the author, most recently, of Iran's Intellectual Revolution (2008) and The Modern Middle East: A Political History Since the First World War, 2nd ed. (2010). His edited volumes include The International Politics of the Persian Gulf(2011) and Innovation in Islam: Traditions and Contributions (2011). 


\section{The Gulf in the Contemporary International Economy}

Fred H. Lawson

As late as the mid-1980s, the Gulf played only a limited role in the international economy. Several states had emerged as major oil exporters, while Bahrain had taken steps to attract international banks as a way to supplement its rapidly diminishing hydrocarbon reserves. But otherwise the region stood at the margins of the global economic order.

Over the ensuing quarter-century, the economic importance of the Gulf states has increased dramatically. The six countries that make up the Gulf Cooperation Council (GCC) and the Islamic Republic of Iran continue to account for a substantial proportion of both output and total proven reserves of world oil and natural gas. In addition, the Arab Gulf states have undertaken a much more extensive range of activities in the global financial system. More recently, the GCC has become a major producer of such heavy industrial goods as aluminum, plastics, and cement, and has started to carve out a niche for itself as a supplier of these products, particularly for the expanding economies of East and South Asia.

In a broader sense, the Gulf now occupies a pivotal position as the generator-of-last-resort of remittances to the labor-exporting areas of South and Southeast Asia. GCC governments have begun to take a more active part in reconfiguring the institutional architecture on which the international economy rests. And the Arab Gulf states and Iran have become key components of the economies of the People's Republic of China and India.

Gulf oil production makes up almost the same proportion of total world production that it did at the turn of the twentieth century, despite an overall increase in global output. The region's contribution to total natural gas production, by contrast, has jumped by more than 50 percent in the decade after 1999. At the same time, Saudi Arabia and the United Arab Emirates (UAE) have become growing suppliers of natural gas liquids, and Qatar is preparing to move into this lucrative new area of hydrocarbon production as well.

Whereas earlier, the great majority of funds generated by hydrocarbon sales were invested in government securities in the United States and West Europe, GCC investments now focus on shares of stock in private companies and investment funds. Meanwhile, Gulf governments are investing more heavily in commercial and industrial projects in the Arab countries of the Middle East and North Africa. Foreign direct investment from outside the region is at the same time flowing into the GCC at unprecedented rates. These trends put the Gulf squarely at the heart of the international financial system.

Aluminum manufacturing got underway in Bahrain in the mid-1970s, and has in subsequent years spread to the UAE, Saudi Arabia, and Qatar. The Gulf Organization for Industrial Consulting estimates that aluminum output in the GCC at present accounts for about nine percent of total world production, and that by 2015 the proportion will double to fifteen percent. A wide range of plastics is now being manufactured in the Arab Gulf states and Iran, and exported to South and East Asia.

Gulf economies contributed a steadily increasing percentage of world remittances during the first decade of the twenty-first century. By 2009, the total amount of remittances paid to expatriate workers in the Gulf exceeded 27 percent of all world remittances. As payments from other parts of the world dried up during the course of the 2007-2008 global recession, monies from the Gulf became an even more vital source of income for many laborexporting countries. 
Saudi Arabia represents both the Gulf states and the Arab Middle East as a member of the Group of 20. The importance of this collection of middle-level economies has risen dramatically over the past three years, and Saudi representatives have taken advantage of their position in the organization to propose fundamental changes to the structure of key multilateral bodies, including the International Monetary Fund.

Trade and investment between Gulf countries and the People's Republic of China (PRC) has expanded sharply in recent years. More important, the particular kinds of goods that constitute the basis of economic interaction have become vital to the PRC's sustained growth. Because the PRC has adopted an "extensive" rather than an "intensive" model of development, Chinese industry requires ever greater supplies of crucial inputs, most notably oil and gas. At the same time, uninterrupted flows of hydrocarbons have become vital to the maintenance of public order in the PRC, especially in the restive provinces of the far northwest.

India's economic growth is equally reliant on commercial, financial, and labor connections with the Gulf. In addition, the GCC has become a major destination for Indian foreign direct investment, including software development, engineering, textiles, chemicals and a wide range of services.

Fred H. Lawson is Lynn T. White Jr. Professor of Government at Mills College. He has edited Comparative Regionalism (2009), as well as Explorations in UAE History (forthcoming 2012). 


\section{The Political Economy of Rentierism in the Gulf}

Mehran Kamrava

Across the Gulf region, state-building processes began in earnest at a time of scarce resources and relative lack of autonomy of social actors with aspirations of acquiring political power. State-building involved two simultaneous processes. On the one hand, it included the creation of various institutions of the state through which political power could be wielded and perpetuated. These institutions included, among others, the army and the internal security forces, the bureaucracy, and such commanding heights of power as the presidency, the official party or parties, the legislature, and judicial branch. At the same time as these institutions were being created, and often through these very institutions, a second process of state-building was unfolding. In most but not all places, this process involved the incorporation of one or more groups of social actors into the state who in turn would become key stakeholders in the maintenance of the evolving political system. These social actors often included resourcerich elites-usually merchants and wealthy industrialists, but on rare occasions also landlords—or the growing masses of the middle classes who became the primary occupants of the countless civil service positions that were becoming available in the burgeoning state bureaucracy.

In consolidating their power, emerging state actors relied on the incorporation of these key stakeholders into the orbit of the state. By the time oil revenues started flowing into the coffers of the state at unprecedented levels, in some cases decades after patterns of state-society interactions had already been forged, political elites were already firmly in control of state resources. The additional rent revenues derived from oil enabled state actors to deepen their incorporation of the different social groups into the orbit of the state, and to devise new ways in which this incorporation took shape.

Not all states, alas, were equally endowed with oil in relation to their population base or geographic size. Iran and Iraq might have had a lot of oil, but they had millions more mouths to feed and salaries to pay, whereas most of the states of the lower Gulf had far smaller populations and much smaller landmasses to worry about. Differences in size - in geography and demography as well as in oil deposits-reinforced differences in preexisting and emerging patterns of state-society relations. By necessity, as bonds developed between the state on the one hand and the social groups it intended to incorporate on the other, the rentier arrangements that took hold in Iran and Iraq became more indirect, more fragile, and less solid. Across the Arabian Peninsula, however, overlaid on historical patterns of "sheikhly rule," rentier arrangements took far more direct forms by strengthening the pre-existing bonds of patronage and clientelism between rulers and the ruled and creating new linkages between them.

This paper calls for a more nuanced conception of rentierism and posits three main points. First, despite fluctuations in revenue sources and significant differences in income levels and sources, rentier political economies remain firmly established across the Gulf, encompassing the six states of the Gulf Cooperation Council as well as Iran and Iraq. These states have little in common in terms of history, institutional make-up, and ideological dispositions and legitimacy. But they do have in common rentier political economies, albeit to varying degrees. Second, the paper argues that emerging rentier dynamics were superimposed on evolving institutional arrangements as state-building processes were already underway. The overlaying of the two has influenced the nature and manner in which the states in question have subsequently evolved. The third argument revolves around 
state autonomy. Even in cases where rent-reliant states enjoy tremendous wealth, rentier arrangements tend to place both the states and their social beneficiaries in positions of mutual dependence on one another, curbing the autonomy of both. That pervasive rentierism tends to inhibit social autonomy is well known. What is important to note is that it also inhibits the autonomy of the state.

Rentier arrangements shape and inform — and in turn restrict— the policy choices and options open to state elites. The starting points of analysis here are the political arrangements and institutions through which Gulf states maintain themselves in power and on which rentier arrangements were later superimposed. Rentierism does not create political arrangements from scratch, especially earlier on in the state-building process. It reinforces pre-existing ones, enabling authoritarian political establishments to enhance their coercive capacities, and deepen their hold on power. It facilitates the development of new modus operandi and institutions that enable the state to more effectively maintain its authoritarian hold on power, placate potential opponents, share its largess with key social allies, and mold social institutions in ways it prefers. 


\section{The Sovereign Wealth Funds of the Gulf \\ Jean-François Seznec}

The Sovereign Wealth Funds (SWFs) of the Gulf are often reported to be very large and growing exponentially as they are fed by the increasing oil revenues of the region. This chapter describes the main SWFs of the region, their modus operandi, their size, and investment philosophy. Many funds in the region provide information on the amounts they manage and, in some cases, the type of investments they have. In such cases, the paper presents publicly available information with comments on the investment philosophies used. However, some of the main funds in the Gulf disclose only minimal information and thus are the subject of wild reports about their size and investment policies. In particular, the Abu Dhabi Investment Authority (ADIA) is often described as the largest SWF in the world and reputed to have constantly stellar performances. This paper proposes a methodology to estimate the actual size of ADIA. It is based on an estimate of actual yearly oil revenues of Abu Dhabi since ADIA's foundation. The method assumes that ADIA is funded by the state of Abu Dhabi only after the basic expenses of the state are paid for. The estimate of inflows into ADIA therefore starts from estimating gross oil income, nets out costs of production, yearly military expenses, state budget expenses and other normal expenses of governments in the Gulf. The resulting balance is assumed to be invested through the Central Bank, the commercial banks and the SWFs of Abu Dhabi, with ADIA getting the bulk of it, here assumed to be $70 \%$ of the funds. The total value of ADIA assets is then computed by including the average return of $6.5 \%$ per year disclosed by ADIA in early 2010 per year.

No two SWFs are the same, hence it can be challenging to find one definition that fits all. The main differences between the many various definitions have to do with the actual control of the funds by the government. A private report by Deutsche Bank summarizes the characteristics of SWFs as follows: 1) sovereign; 2) independently managed from the Central Bank reserves; 3) have a higher foreign currency exposure; 4) have no explicit liabilities; 5) have a higher risk tolerance; 6) have a long-term investment horizon; and 7) potentially could make strategic investments to promote reciprocity back to the country. Below is a description of some SWFs:

Saudi Arabia: All the reserve funds of the Kingdom are invested through the Saudi Arabian Monetary Agency (SAMA) and invested mainly in US dollar short-term treasuries. As of December 2010, the amount held by SAMA for the state and the agencies of the state was $\$ 392$ billion. SAMA publishes the figure monthly and is known for its conservatism and unwillingness to invest in any instruments other than short-term western governments' paper. SAMA views its role as keeper of the wealth of the Kingdom. It seeks to preserve earnings and keep them in highly liquid investments, which can be drawn upon to fulfill the immediate needs of the Kingdom, rather than as a long-term investment in foreign industries or institutions.

Qatar: The Qatar Investment Authority (QIA) manages the funds of Qatar that are not used for the budget and running expenses. It is independent from the Central Bank and invests overseas. QIA is quite secretive, but the total assets of the fund are estimated to be between $\$ 40$ and $\$ 60$ billion. 
Kuwait: Kuwait has had a sovereign wealth fund since 1963. The state computes the yearly income from oil and places $10 \%$ in a special purpose vehicle called the Reserve for Future Generations (RFFG). Today, the Kuwait Investment Authority (KIA), which is under supervision of the Ministry of Finance, manages the RFFG.

UAE: There are four main SWFs in Abu Dhabi, which are funded by the treasury. The funds are managed by a board of directors, which represent the interests of one or more of the clans within the royal family. Each of these funds has a highly professional management. Dubai and Ras alKhaimah also have a couple of funds, but they will not be discussed here for lack of reliable information about their sizes, structures, and leverage.

The Abu Dhabi Investment Authority (ADIA): ADIA is extremely secretive about its activities but, in early 2010, it released some information on its philosophy and returns, but not its size. Currently, 80\% of ADIA's funds are managed by outside fund managers and $60 \%$ are used to replicate indexes worldwide. The fund has returned $6.5 \%$ p.a. for the past twenty years. This return, when applied to the estimates of funds received by ADIA from the Abu Dhabi treasury, allows for an estimate of funds at ADIA of between $\$ 310$ and $\$ 390$ billion. This amount is much less than often estimated, but is still quite staggering.

Mubadala: Unlike most of the other SWFs in the Gulf, Mubadala discloses its assets and liabilities as well as some detail on its portfolio mix and philosophy. Mubadala now has total assets of $\$ 23.4$ billion with a longterm debt level of $\$ 7.4$ billion. The figures are audited by KPMG, and published and distributed through the internet. Mubadala is involved in many different areas, but seems to be mostly involved in oil and gas, industrial investments, aerospace, and real estate.

Other Abu Dhabi Funds: The International Petroleum Investment Company (IPIC) appears to be a strategic investor, taking participations in companies that have substantial involvement in the economy of the UAE such as OMV of Austria, or Borealis of Norway. It also owns NOVA, a chemical manufacturer in Canada and is building a 1.5 million b/d oil pipeline between Abu Dhabi and Fujairah to bypass the Strait of Hormuz. The Abu Dhabi National Energy Company, known as TAQA PSJC is owned by ADWEA, the electricity and water utility of Abu Dhabi, the Farmer's Fund, as well as the public through the Abu Dhabi stock exchange. It invests mainly in utility companies in Abu Dhabi and is highly leveraged with $\$ 25$ billion in assets with only $\$ 3.4$ billion in equity.

Jean-François Seznec is Visiting Associate Professor at Georgetown University's Center for Contemporary Arab Studies. His research centers on the influence of the Arab-Persian Gulf political and social variables on the financial and oil markets in the region. His latest works include a co-edited book Industrialization in the Gulf: A Socioeconomic Revolution (2010), as well as a number of journal articles.

8 The Political Economy of the Gulf | Summary Report 


\section{Knowledge Economies in the GCC States \\ Kristian Coates Ulrichsen}

In recent years, the six Gulf Cooperation Council (GCC) states have embraced the concept of knowledge economies as integral to their ambitious programs of economic diversification. These in turn represent a crucial element of their adaptation to the broader processes of structural changes in the global economy based on accelerating flows of information, knowledge, capital, and humans across state boundaries. Policymakers in the Gulf states utilized a large share of their capital accumulation during the 2002-2008 oil price boom to invest in high-profile and frequently headline-making initiatives in higher education and scientific research. Underlying these moves toward a knowledge-based economic transition is official acknowledgment of the necessity of producing well-educated and qualified workforces able to compete in internationally competitive labor markets and alleviate pressing problems of un- and under-employment. Some of the results have been eye-catching as hubs of agglomeration for knowledge-intensive goods and services impart an added-value dimension to the strategies of economic diversification underway throughout the region.

Nevertheless the strategy to translate oil wealth into human capital integral to the shift toward knowledge economies raises significant questions for the political economy of rentier-state structures in the Gulf states. Central to this is whether the transition toward a knowledge economy is compatible with the maintenance of public sector-dominated redistributive mechanisms of governance. Can the present enclave-based strategies translate into broader cross-sectoral linkages that strengthen autonomous private sector-led developments and institutional capacity-building in the GCC states? Might existing examples of knowledge-creation provide the building-blocks for deepening and widening the economic transition? Is the East Asian model of knowledgeintensive economic development applicable to the different socio-economic context in the Gulf? Is the "revolution" in higher education in the Gulf underpinned by systemic reforms to systems of primary and secondary education and other indicators of human development? What implications might the rise of knowledge-based goods, services, and "economic cities" have on stratified labor markets and the imbalance between the public and private sectors in Gulf states? Will a highly-educated and skilled workforce emerge as agents of transformative change that challenges regime-led top-down patterns of gradual political reform?

Linking this economic transition to socio-political change demonstrates the systemic and interdependent nature of the transition, in which it remains unresolved whether a knowledge economy may be compatible with redistributive, public-sector dominated polities in which the loci of political and economic power are still confined to a relatively closed circle and implemented in a carefully-managed top-down process. If successfully carried out, the reform of economic processes inherent in any fundamental knowledge-based transition would reformulate models of governance and social and political relations in the GCC states. The rise of a productive and knowledge-intensive economy would involve systemic changes to labor markets and require the progressive stripping away of the redistributive mechanisms that have underpinned the concept of the "ruling bargain" for the past four decades. Moreover, the rise of a highly-educated and skilled populace may emerge as agents of transformative change if they perceive limitations to their freedom to access or acquire knowledge or utilize it autonomously from governmental oversight and control. 
This chapter begins with a definitional overview of knowledge economies. This opening section assesses the state of the transitions underway in each Gulf state and contextualizes them within national economic diversification visions and plans. It also lists existing knowledge-production and value-added enclaves that represent examples of the knowledge economy on a micro- and meso-level. A second section moves beyond the empirical framework to examine a number of challenges-and opportunities—-that may arise out of the embedding and maturation of initial openings. It analyzes the reforms to education and higher education and argues that these must be underpinned by the construction of an enabling environment if knowledge-based economic transitions are to achieve takeoff and spread beyond their present enclaves of expertise. The third and concluding section links the analysis to the social and political characteristics of the GCC states and offers a preliminary assessment of the moves toward knowledge economies in the region.

This chapter provides a survey of knowledge economies in the Gulf that pinpointed the current state of affairs as a step in a journey, and not in relation to a fixed start- or end-point. It brings together the critical enabling conditions that will increase the likelihood that this process of change will continue, and highlights the obstacles and challenges that may hold it back. And while the transition toward knowledge economies is a long-term initiative, if offers an interim assessment that progress has undoubtedly been made in areas such as enclave developments and attracting institutions of higher education to the region, but that many of the enabling conditions still await the politically-sensitive and systemic shift toward genuinely post-oil political economies. Buying in imported expertise and prestigious institutions may, on one reading, be seen as consistent with a pattern of throwing money at short-term solutions to longer-term problems of reformulating political and economic structures. The challenge for policymakers in this next phase of development is to link these initial achievements to reform of the wider social and political system and strengthen the enabling conditions that would facilitate the spread of knowledge economies both horizontally across the economic spectrum and vertically into indicators of human capital development and achievement.

Kristian Coates Ulrichsen is a Research Fellow at LSE Global Governance, and Deputy Director of the Kuwait Research Programme on Development, Governance and Globalisation in the Gulf States. His most recent books are Insecure Gulf: The End of Certainty and the Transition to the Post-Oil Era (2011) and The Transformation of the Gulf: Politics, Economics and the Global Order (2011, co-edited with David Held). 


\section{Etatisme Versus Market Driven Islamic Banking: The Experiences of Iran and the Arabian Peninsula Compared Rodney Wilson}

The world's largest Islamic banks in terms of assets are based in the Gulf region: Bank Melli of Iran being first ranked with assets worth over $\$ 57$ billion and Al Rajhi Bank of Saudi Arabia being second, with assets worth over $\$ 45$ billion. Yet, these two banks operate in very different jurisdictions. All banks are nominally Islamic in Iran, whereas on the Arab side of the Gulf, Islamic banks compete with conventional banks. The aim of the chapter is to examine the contrasting approaches taken by Iran and its Gulf Arab neighbors to Islamic banking. The factors that determined these different approaches will be analyzed and their implications explored.

Measuring Islamic bank assets or deposits provides a quantitative indication of relative size, but of greater significance is the dissemination of ideas and the building of international alliances. Spreading the message about the merits of Islamic finance in the Muslim World can be viewed as a facet of "soft power" in contrast to Islamist militancy, arguably a less appealing type of "hard power." The outward globalist approach of Islamic bankers in the Gulf Cooperation Council (GCC) countries contrasts with the inward looking more nationalistic approach in Iran. In particular, the market-driven, competitive model of Islamic banks in the GCC is very different to the statist model of Iran where it is the role of government which is crucial. Ultimately, the future of Islamic banking in Iran will depend on the resilience of the Islamic Republic, whereas in the GCC arguably it is a bottom-up phenomenon with much popular support which governments cannot ignore irrespective of political factors. In other words, in the GCC Islamic banking is primarily seen as a business, whereas in Iran politics has determined developments and will continue to do so.

The concept of étatisme refers to the role of the state in an economy, in particular the state as the architect of structural transformation. In the Middle East context it was applied to Turkey under Atatürk and Egypt under Nasser. In the case of Iran, although the Shah professed economic liberalism, the reality was a strong state that in many respects became even more interventionist after the Islamic revolution which was accompanied by a wave of nationalizations, including that of the banking sector. The constitution of the Islamic Republic states that the public sector should encompass all major industries, foreign trade, as well as banking and insurance. There are no similar constitutional provisions on the Arab side of the Gulf.

Yet the reality in Iran has been more complex, not least because the activity of supposedly charitable foundations was expanded, and they became significant centers of economic power. For example, the Pahlavi Foundation that administered many of the assets of the Shah and his family was taken over by the Foundation for the Disinherited, Bonyad-e Mostazafin. The bonyads are independent of the state but control large amounts of land and industrial enterprises and have their own financial subsidiaries, such as SINA Bank or the Bonyad Finance and Credit Company. These financing subsidiaries are outside the regulatory control of the Central Bank of Iran and are not obliged to produce audited financial statements, nor are they subject to Iran's Islamic Banking Law.

Although Islamic economics is sometimes presented as an alternative to free market capitalism and socialistic policies associated with étatisme and the state determination of resource distribution, in practice Islamists take many different positions on the role of the state. There have been attempts to suggest that there is a single Islamic economic doctrine, but in reality there is a plurality of ideas. In the case of Iran, these were influenced by personality and affiliations, as when Akbar Hashemi Rafsanjani became President in 1989, there was some rolling back in 
the economic role of the state, as he was associated with the bazaaris and consequently sympathetic to the private sector. Nevertheless, although private banking did emerge again and the state banks became more independent from government, banking policy since Mahmoud Ahmadinejad became president in 2005 has remained confused. Directives to lower the cost of financing to below the rate of inflation simply added to inflationary pressures and to a property price bubble that has certainly not been helpful to the urban poor, which have been the president's major source of support. It seems that étatisme is once again gaining ground in Iran, but without any coherent economic or financial policy.

Iran's Law on Interest Free Banking is evaluated and the Islamic credentials of Iran's banking system assessed. There is also an attempt to see how far the economic sanctions imposed by the United States have been detrimental to Islamic banking development in Iran. In practice, sanctions may actually have proved beneficial. The links between Iran and China's rapidly growing economy have been more advantageous than any links there might have been with the sluggish United States economy, had sanctions been relaxed.

The legal and regulatory systems in the Arab countries of the Gulf are examined and contrasted with Iran. Islamic banking development in the Arab countries of the Gulf has been largely ad hoc, with no comprehensive legislation attempting to Islamize financial transactions as in Iran. Within the GCC states, Islamic banking is regarded as a matter of customer choice, with conventional banks competing for business in what is usually described as a dual financial system. Much of the population in the GCC has a preference for banking services which are consistent with Islamic teaching, but many remain to be convinced that Islamic banking as it is currently practiced provides the best solutions, and therefore they remain content to deal with conventional banks, especially for services not provided by Islamic banks. Indeed many Islamic bank clients also maintain accounts with conventional banks without having pangs of conscience, the aim being to get the best of both worlds.

In terms of spreading the message about Islamic finance, GCC-based institutions appear to have been much more successful than their Iranian counterparts. In the GCC, Islamic finance is viewed as a business opportunity rather than being politically driven, and the aim increasingly is to reach a global market rather than being inwardly focused. The GCC-based Islamic banks have attracted considerable media coverage, most of it favorable, whereas in the case of Iran much of the press coverage has been concerned with the effects or possible effects of sanctions. Islamic banking is one non-energy related activity where the GCC has a comparative and, increasingly, a competitive advantage. The future looks promising, as links with the West and other parts of the Muslim World have developed. In contrast, the prospects for Islamic finance in Iran seem much more uncertain, and will be inevitably tied to political developments and the sustainability of the Islamic revolution in its present form, which many question.

Rodney Wilson is Director of the Islamic Finance Program at Durham University. His books include, Economic Development of Saudi Arabia (2004, with Al-Salamah, Abdullah, Malik, Monica \& Al-Rajhi, Ahmed) and Islamic Economics: A Short History (2006, with Ahmed El Ashker). His edited works include, The Politics of Islamic Finance (2004, with Henry Clement) and Islamic Perspectives on Wealth Creation (2005, with Munawar Iqbal).

12 The Political Economy of the Gulf | Summary Report 


\section{Population and Human Capital in the Persian Gulf \\ Djavad Salehi-Isfahani}

The hydrocarbon wealth that distinguishes the countries of the Persian Gulf also gives the dynamics of population and the labor force in the region certain unique characteristics. The massive inflow of foreign exchange into the region has helped raise the standard of living without a corresponding increase in productivity. The gap between income and productivity has shaped the demographic and human resource development of the Persian Gulf countries in two important ways. First, the transition to lower fertility that usually occurs with increased income has been delayed. This transition is generally associated with rising productivity, which increases the opportunity cost of parental time, causing them to reallocate their time away from child rearing to other activities, including child education. But, in the case of Persian Gulf countries, the improvement in living standards has its source in rising incomes from rent rather than productivity, giving rise to a phenomenon of modernization of life style without change in fertility behavior. In Iran, fertility eventually fell to replacement levels in the 1990s, while in Oman and Saudi Arabia it is still more than twice as high.

The second way in which the gap between incomes and productivity has affected human resource development in the region is through the expansion of education. Financed by rising rent incomes and in response to the incentives provided by expanding government employment in the past, the supply of educated local labor has expanded rapidly, outpacing demand from private employers and causing the unusual phenomenon of booming economies with large pools of unemployed educate youth. In the GCC countries, this phenomenon is exacerbated by the policy of liberal import of foreign labor and has further worsened the employment situation for the nationals. In Iran, it is made worse by unusually large cohorts of youth born during the baby boom of the early years of the revolution, around 25-30 years ago. The 15-29 year-old age-group accounts for more than one-third of the total population in Iran, which is a world record.

A fruitful framework that helps us understand the peculiarities of human resource developments in the region is offered by the recent developments in the economic growth literature, initiated by Becker, Murphy, and Tamura (1990) and later developed by Lucas (2002). These theories emphasize the role of technological shocks that raise the returns to human capital in the historic transformation of Western Europe known as the Industrial Revolution, and later in the transformation of East Asian countries. These shocks increase individual productivity, encouraging families to invest more in the education of their children and simultaneously discouraging large families.

In contrast to economic growth spurred by these types of technological improvements, rapid economic growth of the GCC is fueled by rising exports of oil, which does not directly affect returns to human capital, but does increase labor costs. As a result, the incentives to reduce fertility are weaker, delaying fertility transition and allowing the populations of these countries to grow rapidly after incomes have increased to the levels enjoyed in industrial countries. Moreover, because the incentives for investing in education in oil-rich countries derive from greater access to oil rents rather than greater demand for skills on the part of private firms, a mismatch easily develops between the skills taught in formal education and what firms need for production.

With access to vast supplies of labor in nearby countries, especially in South Asia, firms have little reason to

employ the more expensive local educated labor. During the oil boom of the 1970s, import of foreign labor raised the 
growth rate of the labor force in the GCC to historically unprecedented rates ranging from 7 to 10 percent annually. Between 1975 and 1985, the proportion of the non-national workers in the labor force increased from thirty-nine percent to sixty-seven percent (World Bank, 2004). The latest oil boom has seen increases in the labor force of equal magnitudes. In Qatar and the UAE, the share of the non-national labor force now exceeds eighty percent. In the GCC, the policy of easy access to foreign labor and high reservation wages of the nationals has given rise to large pools of unemployed, educated youth. In Iran, where such access does not exist, stagnant labor demand coupled with a rigid labor market that favors older workers has given rise to the same phenomenon.

Another important feature of the labor force in the Persian Gulf countries is the much lower rate of labor force participation of women despite the fact that they are in most countries of the region more educated than men. In Oman and Saudi Arabia, where fertility is still high, this phenomenon can be explained by high demand on women's time at home. However, in Iran, Qatar, and the UAE, where fertility has fallen to replacement level, the explanation lies in the incentives for women to seek education, most likely originating from the marriage market or demand for social status, and not connected to labor demand. As with men, high rent income has increased the reservation wage of women, making it difficult for them to compete with foreign labor in the market of private employment.

The challenge for policy in oil-rich economies of the Persian Gulf is to raise the productivity of the region's educated citizens, men and women, to such high levels that they can compete globally despite their high reservation wages. Success in global competition depends increasingly on a nations' quality of human rather than physical capital. The current economic development strategy in the region of using the hydrocarbon wealth to facilitate the accumulation of physical capital by easy importation of skilled workers is good for accumulation of physical capital, but not for the accumulation of productive human capital. The solution entails diverting much of the oil wealth from accumulation of physical to human capital, but governments have a much easier time in promoting investment in physical capital and formal education than motivating individuals and families to seek globally productive skills. The current strategy of building "knowledge economies" is in the right direction but in its current form falls short because it fails to tackle the incentive problems which promote formal education over skills.

Djavad Salehi-Isfahani is Professor of Economics at Virginia Technical University. His articles have appeared in, among others, Economic Journal, Economic Development and Cultural Change, Journal of Development Economics, Journal of Economic Inequality, International Journal of Middle East Studies, and Iranian Studies, and Middle East Development Journal. He has also edited Labor and Human Capital in the Middle East: Studies of Markets and Household Behavior (2001), and co-edited The Production and Diffusion of Public Choice Political Economy (2004). 


\section{The GulfMonetary Union \\ Alexis Antoniades}

January 2010 was the targeted date for countries of the Gulf Cooperation Council (GCC) to launch the Gulf Monetary Union (GMU). Had these countries succeeded, the GMU would have been the biggest monetary union outside Europe with an economy as big as Germany's and an area almost half the size of the Eurozone.

The move by the six oil-rich Gulf countries to adopt a single currency would be the final and most far-reaching part of the Unified Economic Agreement that was signed by the GCC countries almost thirty years ago. It would also be an unprecedented event. GCC countries account for $45 \%$ of the world's proven oil reserves and $17 \%$ of the proven natural gas reserves. The stability of the global economy depends on the ability of these countries to maintain a smooth supply of oil at a fair price. At the same time, any decision of the countries to move away from the U.S. dollar peg can exacerbate global imbalances, by adversely affecting the value of the U.S. dollar.

As I write this article, it is obvious that the launch of the GMU has been postponed. The impact of the global financial crisis, the slow progress that the member states have made towards fulfilling some of the accession criteria and harmonizing their economies, and the decision of Oman and the United Arab Emirates to drop out of the negotiations in 2006 and 2009, respectively, are some of the factors that contributed to the delay. Whether the union will be established—albeit with a delay_or not remains unclear. It is also unclear whether the Gulf countries are closer now to establishing the GMU than they were five years ago. I think they are not.

The decision to establish the Gulf Monetary Union is a political one, driven by a single goal: to maintain and enhance political stability in the Gulf through unity. By establishing a bigger political constituency, the GCC countries as a bloc, increase their bargaining power and they can overcome external threats, especially from Iran and Iraq. Moreover, moving to a single currency makes the expectation of a move away from the U.S. dollar more credible, and gives the bloc more leverage at the negotiating table.

Since the GMU is driven by political considerations, we must recognize that the decision to postpone or even abandon the launch will not depend on the economic advantages and disadvantages. It will reflect the political environment within the GCC countries and the political will of the rulers.

The key political cost of the GMU, if it comes to pass, will be the surrendering of policy autonomy at the national level. How big the cost is for the member states depends on their ability to maintain national unity and avoid internal conflicts while pursuing a common external policy at the bloc level. In 2003, Saudi Arabia did not openly support the U.S. war on Iraq in order to maintain national unity, while the other GCC states endorsed the U.S. efforts. Had the Gulf Monetary Union been in place, it would have been more difficult for the Saudis to deviate from the consensus, for such an action would damage the credibility of the GMU. At the same time though, Saudi Arabia would have faced the risk of internal conflict. Many Saudis cite internal conflict as the cause for the demise of the first and second Saudi states in the 19th century, which is a history they would rather not repeat.

The magnitude of the political cost associated with the surrendering of policy autonomy at the national level also depends on whether decisions are taken by consensus in a democratic environment or dictated by Saudi Arabia. That is not to say that Saudi should not have more voting power. After all, Saudi Arabia accounts for 70\% of the population and $88 \%$ of the total land in the GCC. But the decision makers must ensure that the views of all member states are taken into consideration and that the policies promote the interest and well-being of the GMU as a whole, 
and not the interests of individual countries. The timing of the UAE's exit from the GMU is not random. It came after it was announced that the regional Central Bank would be located in Riyadh and not in Abu Dhabi.

Turning to economics now, the GMU will have a positive, yet limited impact in the short-term. Getting rid of the local currencies in favor of a single currency lowers transaction costs, eliminates nominal exchange rate risk, and increases trade among the GMU members. How big will the increase in trade be? Not much. In the case of the European Monetary Union (EMU), trade at the bilateral level within the EMU increased by 5 to 15\%, although not all of the increase can be attributed purely to the EMU. For the case of the GMU, the increase in trade will be smaller since there is less bilateral trade among the GCC countries than there is among the EMU countries.

On the bright side, the two main economic disadvantages of monetary unions-loss of monetary autonomy and loss of the ability to use exchange rates as an automatic stabilizer-are not a major concern for the GMU countries. The countries gave up monetary autonomy and the ability to use exchange rates as automatic stabilizers when they pegged their currencies to the U.S. dollar. Kuwait is an exception; it chose to move away from the dollar peg in May of 2007. It now pegs the Kuwaiti dinar to a basket of currencies, although it is widely believed that the U.S. dollar dominates the basket. As a result, the currency does not fluctuate much with respect to the U.S. dollar. Actually, moving to a single currency can eventually help them gain back monetary autonomy and control over their currency.

To my assessment, the biggest gains from the GMU will be neither political, nor economic. They will be institutional. A successful monetary union requires discipline, transparency, accountability, institutional independence, well-developed analytical capabilities, coordination, and communication. It also requires that each country expands its research capacity and improves the quantity and quality of data that it produces.

So whether the GMU is established and when is not that important. What is most important is whether along the transition path, the countries work on the technical requirements above. If they do so successfully, the quality of institutions in each country will be much improved, and stronger institutions will bring long-term growth, improved welfare, and enhanced stability with or without the GMU.

Alexis Antoniades is Visiting Assistant Professor of International Finance at the Georgetown University School of Foreign Service in Qatar. Funded by a \$1,050,000 grant from the Qatar National Research Fund, Antoniades has undertaken the first micro-study of the Gulf economies that is based on scanner level price data. He also serves as a Senior Advisor to the Qatar National Research Fund at the Office of the Heir Apparent in Qatar.

16 The Political Economy of the Gulf | Summary Report 


\section{The Dubai Model: Diversification and Slowdown}

Christopher Davidson

Since 2008, the economic development model employed by the United Arab Emirates' second wealthiest and historically most autonomous emirate of Dubai has gone from being an exemplar of post-oil diversification for the region to being a warning on the perils of over-reliance on foreign direct investment and credit-fuelled growth. The world's leading newspapers posted dozens of articles—with varying degrees of accuracy-detailing Dubai's perceived collapse.

This chapter provides more substance and perspective to these accounts, arguing that Dubai's current economic crisis is not only a product of the global credit crunch, but a direct consequence of the new economic sectors that were introduced in the 1990s, the speed with which they were developed in the 2000s, and the debts incurred in the process.

With this aim, an overview of the "Dubai model" is provided, explaining the motivation and rationale behind the various diversification strategies pursued by "Dubai Incorporated" or "Dubai Inc." - the business-oriented government of Sheikh Mohammed bin Rashid Al-Maktoum, Dubai's hereditary ruler. In particular, the chapter focuses on Dubai's recognized need for reducing dependency on oil and gas exports and its early role as a free port, before turning to its building of advanced commercial infrastructure and manufacturing and agricultural sectors. The setting up of giant export processing and investment "free zones" to harbor foreign companies is then examined, along with the emirate's establishment of luxury tourist and real estate industries and the necessary economic liberalization required by these sectors. The impact of the global credit crunch on Dubai is then considered, especially the emirate's inability to re-service debts and its reliance on bailout packages from its fellow UAE member, Abu Dhabi. Finally, the chapter questions the level of autonomous control Dubai Inc. can still have over its economy in the wake of such substantial assistance from oil-rich Abu Dhabi.

Without sizeable hydrocarbon reserves, Dubai's economic development has had to focus on more urgent diversification from oil exports and oil-backed investments than Abu Dhabi. Although Dubai's manufacturing sector grew in the 1970s and 1980s, most of the activity was on a fairly small scale. The most emphasis was placed on reinforcing the emirate's historic role as a regional trade hub by building up transport and communications infrastructure. Since the mid-1980s, Dubai also began to seek foreign direct investment, initially by setting up "free zone" industrial parks that would allow foreign companies to relocate to Dubai and enjoy 100 percent ownership without need of local business partners. Since then, many other free zones have opened, including entire "villages" for branch campuses of foreign universities and health clinics, and even an international financial center.

In parallel to the free zone strategy, Dubai also committed to building up a luxury international tourist industry. By 2008, with hundreds of hotels, the emirate was hosting over six million tourists a year. And backed by a successful airline, two annual shopping festivals, over forty shopping malls, and a host of international sporting and music events, the number of tourists was predicted to climb to ten million or more by 2012. To attract investment from wealthy individuals, a real estate sector was introduced in the late 1990s. Although controversial, given that it was against UAE law for foreigners to own property at that time, Dubai bypassed this complication by initially allowing foreigners to buy renewable leases, and then in 2006 allowed full freehold 
ownership for foreigners. By the summer of 2008 Dubai had succeeded in diversifying its economy, with the nonoil sectors accounting for more than 95 percent of the emirate's GDP.

However, as the global credit crunch entered into its second year, Dubai's economy was already experiencing difficulty. Foreign investors' interest in real estate was declining markedly and hotel occupancy rates began to falter as tourists turned to cheaper destinations. Most seriously, Dubai's banks and mortgage lenders were struggling to find credit on the international market and it was revealed that state-backed companies had accumulated a debt of more than $\$ 80$ billion, most of which was due for re-servicing over the next few years. By February 2009, Dubai was effectively bankrupt as it struggled to service even the first of 2009's major debt renewals. Since then, the emirate has had little option but to seek substantial assistance from Abu Dhabi. At present, it is unclear what the full economic and political implications will be with regard to Dubai's position in the UAE, but there are already indications that Abu Dhabi is seeking to underscore-subtly at least—its primacy within the federation.

Christopher Davidson is a reader in Middle East politics at Durham University. He is the author of Persian Gulf and Pacific Asia: From Indifference to Interdependence (2010); Abu Dhabi: Oil and Beyond (2010); and Dubai: The Vulnerability of Success (2008). His edited volumes include, Higher Education in the Gulf: Shaping Economies, Politics, and Culture (2008) and Power and Politics in the Gulf Monarchies (2011). 


\section{Good, Bad, or Both? The Impact of Oil on the Saudi Political Economy Steffen Hertog}

In the face of significant economic diversification in the GCC, the consensus that oil is bad for development seems to be crumbling - at least when it comes to high-rent countries such as the oil monarchies of the Gulf. But no new paradigm has replaced the "resource curse" school. Based on the Saudi case study, this paper argues that it is difficult to systematically assess the impact of oil on development as long as 1) the yardstick of what is good or bad has not been clearly defined, taking into account the appropriate counterfactuals; and 2) as long as development results are not disaggregated on a sectoral or institution-to-institution basis.

The argument developed is that compared to where it would arguably be without oil, Saudi Arabia clearly has achieved impressive development results on most run of the mill indicators of economic and institutional maturity. We should not be confused by the fact that it scores worse than non-oil countries with comparable GDP per capita. The more relevant "control group" are developing countries, to the poorer segment of which the kingdom would probably belong to if oil had not been found eight decades ago. On most indicators, Saudi Arabia scores better than most members of this group.

Secondly, institutional and development results within the kingdom differ drastically depending on which segment of the system one looks at. While in some cases, typical "resource curse"-style ailments have undoubtedly set in, other institutions have developed high levels of efficiency thanks to the availability of prudently deployed oil income. Analyzing nationally aggregated results obfuscates more than it reveals about the impact of oil on development. At least under conditions of a politically autonomous state elite, oil income dramatically enlarges the menu of institutional choices. It allows the expansion of patrimonial fiefdoms and of mass patronage at the same time that it enables the elite to create politically protected and well-endowed islands of institutional efficiency.

Adding to my previous work on the Saudi political economy, the paper briefly discusses the internal functioning of each of these types of institutions, commenting on recent developments in all of them, with special focus on institutions of mass distribution and their expected long-term trajectory. While building a heterogeneous state has been an expedient means of allowing institution-building in the context of an underdeveloped economy and a patronage-based political system, the long-run fiscal burden imposed by a redundant and fragmented state apparatus is likely to become unbearable. The paper discusses the limits of the "islands of efficiency" model against this background, as well as the apparent path-dependencies that make it harder to shift from a model of enclave development to one of more diffuse innovation, growth, and value generation.

The final section of the paper puts Saudi Arabia in regional comparative perspective and discusses to which extent it has, against all our expectations, functioned as a "developmental state:" defined by a combination of deep state intervention with a pro-capitalist orientation, active formal and informal state guidance of business and an important role of the public sector, a Weberian bureaucracy in important lead agencies, export orientation and rapid, successful industrialization. Different from East Asian developmental states, however, the Saudi state combines these features with the parallel existence of large, wasteful fiefdoms and mass distributional arrangements. The latter would be unthinkable in a developmental state whose resources are derived through domestic resource extraction, and in which tough decisions on fiscal priorities have to be made in the course of state-building. Related to the availability of external resources, development in Saudi Arabia also does not involve the bulk of the populace, which 
has been deeply implicated in development in East Asia through "forced savings" or at least an unusually large industrial work effort.

Saudi Arabia is not the only segmented system in the GCC: Bahrain, the UAE, and Qatar also have redundant and fragmented state apparatuses with administrative bodies of often dramatically variegated quality, created rapidly and in a top-down fashion through discretionary rent allocation by a fairly autonomous elite. Oil has been used for radically different purposes, increasing the heterogeneity of the state rather than having a uniform effect on institutions. In the UAE and Qatar, royal fiefdoms and mass patronage employment coexist with technocratic islands of excellence. In Bahrain, a whole parallel government of "ad-hocracies" has been created during the last decade in order to circumvent the opaque and slow-moving regular state apparatus.

But due to its population size, Saudi Arabia is probably the GCC country in which the segmented state will be put to the most severe test in the coming decades; an economy of 30 million cannot forever be run through enclave structures. A de-segmentation of the system would require painful bureaucratic and labor market reforms that the leadership does not seem willing to tackle for the time being-and that might have become even harder in the context of the recent regional turmoil.

Steffen Hertog is a lecturer in comparative politics at the London School of Economics and Political Science. He has published in journals such as World Politics, Review of International Political Economy, Comparative Studies in Society and History and International Journal of Middle East Studies. He is the author of Princes, Brokers and Bureaucrats: Oil and State in Saudi Arabia (2010). 


\section{The Political Economy of Rentierism in Iran \\ Massoud Karshenas and Ziba Moshaver}

In this study we have examined the evolution of rentierism in Iran by focusing on the interactions between oil income and the development of the state in a historical perspective. Our analysis is based on the view that the concept of a rentier state in general and abstract terms is not adequate to explain the complex processes and outcomes in the development of oil economies such as Iran. As we have argued, these developments are to a large extent context specific and path-dependent. Viewed in a dynamic context, however, the role of oil income in the formation of state structures and the outcome of state interventions also becomes prominent. These complex interactions are analyzed by highlighting the nature and development of the rentier state during various phases within two distinct eras, namely the Pahlavi era and the post-revolutionary Islamic state.

In the first phase of the Pahlavi era, namely, the inter-war period, oil revenues were relatively low and the economy was too archaic for oil to have a direct impact on economic development. Nevertheless, the role of oil income was critical as it facilitated the creation of the modern state and the emergence of centralized state institutions. This was itself a precondition for modern economic development and improved bargaining power vis-a-vis the oil companies and higher oil revenues in subsequent periods.

One of the prominent aspects of the development of the modern state system pertained to the oil sector itself and its relation to the budgetary processes of the state. Modernization of the state during the 1920s led to the emergence of more transparent formal budgetary processes and the separation of the government budget from the personal prerogative of the sovereign. As a result, oil revenues accrue to the government through the national banking system and are reflected accurately within the public sector accounts. This marks an important difference with some other oil rich countries in the region where oil revenues are still mainly controlled by the sovereign who allocates a part to the government budget.

The building of centralized state institutions helped by oil revenues in this period also contributed to the strengthening of the authoritarian tendencies of Reza Shah. However, with the allied occupation of the country during WW II, and Reza Shah's fall in 1941, a new era of open politics and increased parliamentary activism began. This period is marked by participation of different political groupings and tendencies, especially the emergence and consolidation of the liberal democratic centrist party: the National Front. This resulted in the coming to power of the first democratically elected government in Iran under the premiership of Dr. Muhammad Mussadegh and the subsequent nationalization of the Iranian oil company.

This democratic experience was aborted by the combination of a prolonged economic boycott and finally by a U.S. initiated military coup in 1953 . The post 1950 s period witnessed a considerable rise in oil revenues of the government and ushered a period of sustained growth of oil exports up until the mid-1970s. The economic system during this phase was a mixed market economy within the framework of five year development plans. Government planning encouraged private sector activities and was important for the growth of a thriving private sector, and became instrumental in creating a new class of private industrialists. Other important measures included the land reform program of the 1960s, coupled with other important reforms which constituted the so-called White Revolution. These reforms evidently required expansion of the state bureaucracy and connected various social strata more tightly with the state system and central government. 
This period of relatively balanced growth during the 1960s and 1970s, which was made possible by giving a greater degree of autonomy to the technocratic elements within the state, was interrupted with the oil boom of 1972-1974. The oil boom once again increased the autocratic nature of the Shah's rule, whose growing interferences led to an overheated economy characterized by wasteful and ambitious investments, bureaucratic and administrative expansion, and high defence and security expenditure.

With the end of the oil boom era, from the mid-1970s, the economy entered a recessionary phase with growing economic imbalances giving further impetus to social tensions. Whether the Shah and the autocratic political and economic order could manage the necessary reforms, as for example implemented in South Korea and Turkey in a similar juncture, could not be tested as the 1979 revolutionary upheavals changed the course of history and ushered a new phase of rentierism in Iran.

The emergence of the Islamic Republic after the 1979 revolution brought about a radical transformation of the political economy of oil and development in Iran. The Constitution of the Islamic Republic laid the foundation for a dual state whereby the official state structures, namely the elected parliament and the executive, live side by side with an unofficial network of institutions controlled by the clergy and headed by the supreme leader. We have referred to the latter as the unofficial "core state." The core state controls important state apparatuses such as the judiciary and the security forces. Furthermore, through institutions such as the Guardian Council, it screens candidates for parliamentary and presidential elections, has veto power over the legislation passed by the parliament, and exerts considerable influence over day-to-day affairs of the elected official government.

The official state institutions are designed to work within a framework of bureaucratic rules and laws ratified and upheld by elected representatives. The unelected core state, on the other hand, operates mainly as a network of individuals and interest groups wielding power through informal and sometimes interpersonal relations and their actions are not governed by transparent and bureaucratic rules and regulations. As argued, the events immediately following the revolution, as well as the war years of the 1980s, played an important role in the formation of this dual state. This duality has had immense repercussions, particularly with respect to the state-economy interactions, and the role of oil resources in the political economy of post-revolutionary Iran. This pertains both to the nature of new economic institutions which have emerged under the Islamic Republic, such as the bonyads (foundations), as well as the dynamics of economic change and the evolution of these institutions. For example, as discussed, concepts such as privatization, and the very notion of private/public distinction take different meanings within this configuration of state power. The fate of the various attempts at economic reform since the 1990s has also been very much shaped and undermined by the interplay of forces within this dual state configuration.

An important aspect of economic change since the 1990s has been a considerable shift of economic power from the official elected government - the "legal rational" arm of the state - towards the less transparent and more murky and informal core state, with the independent private sector becoming increasingly marginalized. The expanded economic position of the core state is not confined to the accumulation of assets within the institutions under its direct control such as the bonyads and the Revolutionary Guards. It also works through indirect interventions and government regulations of foreign exchange markets, interest rates and allocation of bank credits, as well as rationing

22 The Political Economy of the Gulf | Summary Report 
and direct price controls of a large section of product markets. As demonstrated, the result has been a glaring rise in allocative and productive inefficiencies in the system, and increased dependence of the economy on oil revenues.

Some of the glaring price distortions resulting from the system of multiple exchange rates which plagued the economy for much of the life of the Islamic Republic appear to have been remedied since the exchange rate unification of 2002. Nevertheless, with huge subsidies for strategic products such as energy and basic foods, price distortions still remain important impediments to the allocative and production efficiency of the system. The huge energy subsidies have inevitably led to the use of inappropriate technologies and have created the appearance of profitability in activities which remain non-competitive by international standards.

The glaring production inefficiencies observed in the economic system under the Islamic Republic once more raises the question of whether the system has the necessary flexibility to conduct the necessary reforms.

Massoud Karshenas is Professor of Economics at the School of Oriental and African Studies at the University of London. His publications include, Social Policy in the Middle East: Economic, Political and Gender Dynamics (2006); Industrialization and Agricultural Surplus: A Comparative Study of Economic Development in Asia (1995); and Oil, State and Industrialization in Iran (1990).

Ziba Moshaver specializes in international relations and Middle East politics. She has widely published on aspects of the politics of the Indian subcontinent and the Middle East. Her publications include, The State and Global Change: The Political Economy of Transition in the Middle East E North Africa (2001, co-edited with H. Hakimian), and "Revolution, Theocratic Leadership \& Iran's Foreign Policy" in Analyzing Middle East Foreign Policy, (2005, edited by Gerd Nonneman). 


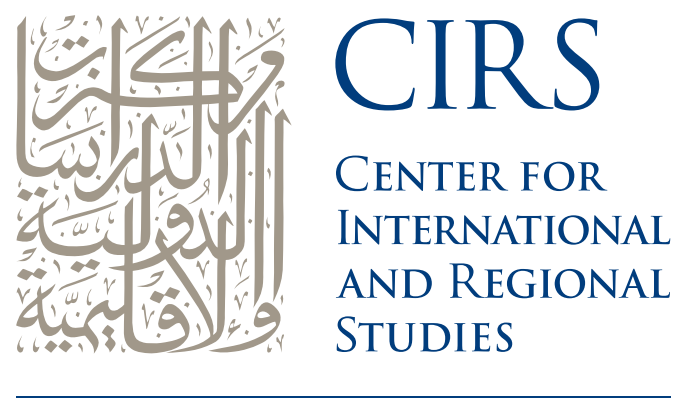

GEORGETOWN UNIVERSITY SCHOOL OF FOREIGN SERVICE IN QATAR 


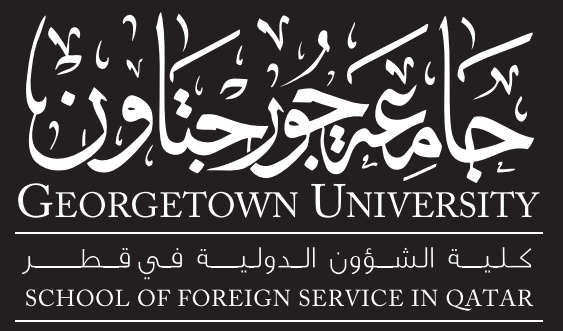

(C) 2011 Center for International and Regional Studies Georgetown University School of Foreign Service in Qatar

Qatar Foundation

P. O. Box 23689

Doha, State of Qatar

http://cirs.georgetown.edu cirsresearch@georgetown.edu

Tel +97444578400

Fax +974 44578401 